\title{
MOTIVES FOR CIVIC INTEGRATION: POLISH IMMIGRANTS IN ICELAND
}

\section{Monika Nowicka*}

\section{Abstract}

The purpose of the article is to reconstruct the reasons why Polish immigrants in Iceland want to apply for Icelandic citizenship. As a result of the analysis, four main motivations for adopting Icelandic citizenship were distinguished: 1) the possibility of visa-free travel to the USA; 2) applying for citizenship "just in case"; 3 ) obtaining rights that only the Icelanders have and 4) the ability to decide about the fate of the community in which immigrants live. The analysis is based on semi-structured in-depth interviews carried out in Iceland in 2014.

Keywords: civic integration, naturalization, Iceland, citizenship, immigrants

Creating the English-language version of the journal "Zoon Politikon" is financed under contract No. 724/P-UN/2018 from the funds allocated by the Minister of Science and Higher Education for dissemination of science.

\footnotetext{
*Monika Nowicka, Ph.D., Collegium Civitas, Warsaw, Poland, e-mail: monika.nowicka@civitas.edu.pl ORCID: https://orcid.org/0000-0002-0430-8251
} 
Introduction

Since 2007, Poles have been the largest immigrant group in Iceland. The inflow of Poles was primarily caused by the opening of the Icelandic labour market in 2006. However, due to the 2008 crisis, there was a reduction in the number of Polish workers on theisland between 2009 and 2011. Then again, since 2012, the number of Poles has been systematically growing and in 2017 it reached 13,811. This constituted $4 \%$ of the entire population and $30 \%$ of all immigrants (Statistics Iceland 2017).

Polish mobility to Iceland is a part of the post-accession, "liquid" migration, characterized by the lack of predictability and the definition of its time, geographical and functional scope (Okólski 2009, p. 30). Liquid immigrants can flexibly react to socio-political and economic changes in the host country and shape their migration paths accordingly. Post-accession migrants have stopped making far-reaching plans and readily consider another mobility if such a step appears necessary. Thus emigration ceases to be associated with settlingin the host country and becomes an open project.

The aim of the article is to reconstruct 1) the reasons why Polish immigrants in Iceland choose to get naturalized and 2) types of civic integration. The analysis is based on 39 semi-structured in-depth interviews carried out in Iceland in 2014. There were conducted: 17 individual conversations with the so-called "ordinary immigrants", i.e. people who did not engage in the public life of the Polish minority in Iceland, and 17 "leader interviews" with activists of Polish diaspora organizations in Iceland. The leader interlocutors were approached as objective informers, but they often recounted their personal migration experiences as well.

Three group interviews with the representatives of following Polish associations operating in Reykjavik: Projekt, Polska.is and the Association 
of Friends of the Polish School in Reykjavik, the Polish-Iceland Friendship Society were held. The interviews were carried out at three locations: in Reykjavik; Akureyri (Northern Iceland) and in Reyðarfjörður (Eastern Iceland). The article is based on the results of the research contucted for my doctoral thesis.

Assimilation and integration as immigrant adaptation strategies

The issue of immigrants' adapting to the host society is one of the key problems in sociology and is increasingly the subject of lively political and social debate (see Murray 2017; Scheffer 2011). In the social sciences, four main adaptation strategies can be distinguished: assimilation, integration, separation and marginalization. Of these, assimilation, closely related to the American sociological tradition (Glazer 1993; Trevena 2008), has the longest history of sociological interest.

Researchers have not agreed on a common understanding of assimilation (just as they have not in the case of the other terms) and paradoxically analyze it in relation to integration. Assimilation is a onesided process that is supposed to lead to the inclusion of a minority group in the majority group so that the minority becomes unrecognizable (Kellor 1913 cited after Glazer 1993).

Understanding of assimilation has been changing over time change. Various dimensions of the process have become the focus of research (Gondon 1964); it is no longer seen as a universal way of incorporation of immigrants (Morawska 1994); it has been noted that immigrants do not have to assimilate to only one pattern, that of WASP culture, but there is now the possibility of assimilation to various segments of society (Portes, Zhou 1993). Interestingly, an assumption has been made that assimilation also applies to the receiving group, which must change in order to reconcile differences resulting from ethnicity (Alba, Nee 2003). 
Integration is a concept subsequent to assimilation; it is related to the European tradition of describing the inclusion of immigrants in the host society and is a much more problematic and the concept of assimilation. Integration does not require the immigrant to depart from their culture and tradition. It defines the state in which immigrants, "while maintaining their cultural identity, enter into relatively permanent relationships with the host society and participate in various areas of its life [...]; [integration also means that - $\mathrm{MN}$ ] immigrants develop respect for the basic norms, values and institutions of the host society" (Grzymała-Kazłowska 2008, pp. 35-36).

Integration understood this way is a one-sided process: only minority group needs to change Integration can also be defined as a two-way process requiring adaptation of immigrants to the host society, and the host group and its institutions to the newcomers (Castles et al. 2002). Integration can also be seen from the perspective of the immigrants themselves: the immigrant has been integrated when they feel to have become part of the host community, and "that feeling of belonging is a reflection of integration within social networks and institutions" (Wu, Schimmele, Hou 2012, p. 383). Integration can also be understood as a strategy in which an immigrant wants to maintain their culture and at the same time is looking for contact with the other culture (Berry 1997).

For the needs of the analysis, I assume that integration is a strategy in which an immigrant functions in both the host society and the society/ community they haveleft. With regard to citizenship, this will mean that obtaining the citizenship of the host country while keeping the citizenship of the country of their origin, is a manifestation of integration as an adaptive strategy ${ }^{1}$.

\footnotetext{
' Adopting the Berry's model, three other adaptation strategies related to citizenship can be distinguished: 1) assimilation, when the immigrant acquires the citizenship of the receiving state, renouncing at the same time the citizenship of the sending country, 2) separation, when the immigrant does not apply for citizenship of the host country and retains the nationality of the sending state, 3) marginalization, when the immigrant does not apply for citizenship of the receiving country and loses the citizenship of the sending state.
} 
Factors affecting the integration of immigrants

Ager and Strang (2004) distinguish four groups of factors influencing integration: 1) means and makers, including employment, housing, education and health; 2) social connections, i.e. the social capital available to an immigrant; 3) facilitators, including the knowledge of the local language and culture as well as security and stability; 4) foundations, i.e. citizenship and rights. According to the authors, the presented groups of factors do not have to be read either hierarchically or sequentially. Citizens' rights can be defined as both the basis and the factor necessary for further integration, as an accomplishment of the integration process or in parallel with other elements as a supporting factor.

Other researchers most often distinguish groups of factors associated 1) with the host society and its institutions, 2) with the ethnic community of the immigrant, and 3) related to the migrant itself.

Alba and Nee (2003, kl 551) distinguish two kinds of assimilation mechanism: proximate causes operating at the level of individuals, primary groups and communities (at the network level) and distal causes, which have their origin in the institutions of the host society. Proximate mechanisms are shaped, among others, through the forms of capital individuals possess. Individuals are defined as entities undertaking purposeful actions aimed at improving their wellbeing. In the process of making choices, immigrants have only incomplete information to work with and they tend to take into account their cultural beliefs, which shape their understanding of what constitutes their own interest. Distal mechanisms are "incentives embedded in the institutional environment" (2003, kl 722). Immigrants have unequal access to various types of opportunity structures (e.g. to the labor market or medical care), which also affects one's ability to undertake an integration strategy. 
Hartmut Esser (2010) created the Model of Intergenerational Integration to reconstruct mechanisms explaining the results of immigrant integration to the host society. The model consists of three elements: the options that immigrants have at their disposal; the basic functions, which constitute a link between the options and empirical conditions; and structural outcomes, which are the aggregated result of individual choices.

The basic options consist of 1) the context of the host society and 2) one's ethnic context. Taking action in each of these two contexts leads to a certain number of negative or positive returns from the action taken (Esser calls it the $E U$ weight ). Individuals take those actions that bring the highest returns. An immigrant calculating whether a given activity is profitable takes into account their own resources (capitals: cultural, economic and social) and their value in the context of a) the receiving society; b) their ethnic community. In order to be able to achieve the goals set by the host society, immigrants must invest in the capital that has the highest value for the host society, e.g. language learning. Being a very expensive investment, language learning, paradoxically, may not guarantee returns that could lead to the immigrant's upward movement in the socio-economic structure. In such a situation, the immigrant may choose to act in their ethnic context alone, thus separating themselves from the host society.

In the above model, two basic functions are also important: 1) the immigration group size and 2) ethnic boundary making. The former depends on a) the absorption of immigrants by the host society; b) the inflow of new immigrants. The latter is built on two foundations: a) structure (boundaries arise as a result of spatial or structural segregation); b) mental attitudes (they are the result of one's prejudices). Strong ethnic boundaries discourage an immigrant from acting in the context of the and encourage to do so in the ethnic context. 
To explain the motives of theimmigrants' decision to get naturalized, I propose a model combining both theoretical proposals. In accordance with the above definition of integration, immigrants do not have to choose between the context of the host society and that of their ethnicity; if they consider it profitable, they can function in the two simultaneously. Profitability is the result of a calculation influenced by the resources possessed by the immigrant (proximate mechanisms) and their habitus as well as structural considerations (distal mechanisms). I suggest that the latter group of mechanisms be extended so as to include the structural border making of the civil community, rather than be limited to culture, economy and space.

\section{A sociological concept of citizenship}

Citizenship refers to membership in a political community; in the modern world, it is a status that links an individual to a nation state. For most people, citizenship is an assigned status therefore they do not think about how they acquired their civic rights, what these rights give them, or what shape their life would take without them. The situation changes when one decides to emigrate to a new country, and citizenship can become one of the key issues of individual's everyday life (J oppke 2010 , p. 34). While the migrant can usually take their family and money along with them to the new country, speak their native language and practice their cultural habits; their citizenship and the resulting rights (and duties) are left behind, in the home country. In the case of an immigrant, the civic status ceases to be their natural attribute and starts to be seen as an inclusion/ exclusion tool, with the help of which undesirable individuals/groups can be left outside the political community.

In the era of global migration, granting the status of a citizen is an issue for receiving countries, which carefully and precisely adopt legal solutions for naturalization of immigrants. Depending on the policy of 
a given country, naturalization of an immigrant may be the final step of the integration process or its prerequisite (Ager and Strang 2004).

Castles and Davidson (2000, p. 84) distinguish two aspects of civic integration of immigrants: that of becoming a citizen (access to citizenship), which culminates in receiving the passport of the hosting state (citizenship as the culmination of the integration process) and that of substantial citizenship, which implies equal opportunities for participation in various areas of social life, such as politics, the labour market, social security and culture (citizenship as a prerequisite for integration).

Therefore, citizenship is on the one hand a status, and on the other a social role connected with the status (Raciborski 2010, Bukowska, Wnuk-Lipiński 2005).

Citizenship, like many other terms in social sciences, is an ambiguous concept. Ulrich Preuß (1993, p. 85) distinguishes three meanings of the term citizenship: 1) it can be a legal concept denoting nationality; 2) it can be viewed "as active co-participation and involvement in the political life of society"; or 3) as participation in civil society, i.e. in the area whose "structures and forms of agreement are created and determined not by the supreme state institution but are the result of non-state political forms of communitarisation".

Blomeraad et al. (2008, pp. 155-158) distinguished four dimensions of citizenship: 1) citizenship as a legal status (how it is available for specific groups; 2) citizenship as a right (how mutual rights and obligations are defined in a contract between the state and individual); 3) citizenship as political participation; 4) citizenship as belonging (how the rules of inclusion and exclusion are established).

Thus, citizenship can be seen in the following dimensions: state versus non-state and status-based versus participatory, as well as in native versus foreign. Citizenship can also be considered in a formal aspect related to the legal status of individuals and to that of active citizenship. For the needs of the analysis, citizenship is understood as 
a contract between the state and the individual that specifies the rights and obligations of the two parties.

Naturalization of Poles in Iceland - distal mechanisms

Until recently, citizenship was closely related to the national state, whose borders determined the area in which citizen's rights were in force. With the establishment of European Union citizenship in the Maastricht Treaty (1992), citizen's rights, or at least some of them, had crossed the borders of nation-states. The boundaries of the civic community had thus been set at a supranational level. Consequently, citizenship as an inclusion/ exclusion tool had been weakened, as the rights derived from the status of a citizen are now available to all EU citizens working within the Union. UE migrants find themselves in a completely new situation - naturalization is not necessary for them to be able to enjoy social, civil and political rights. This is the case of post-accession emigrants from Poland to Iceland.

Icelandic regulations on the naturalization of foreigners have changed several times since 1918. Currently, according to Article 8 of the Icelandic Nationality Act (1952), an applicant should have been resident in Iceland for 7 years, or for 4 years in the case of citizens of another Nordic country ${ }^{2}$. Other requirements refer to the applicant's financial situation and criminal record. The specifically Icelandic requirement is the necessity to provide written statements about the applicant's good reputation from two Icelandic citizens. The applicant must also pass an Icelandic language exam. The decision on granting citizenship is taken by Parliament. Currently, there is no obligation that a successful applicant should renounce their first citizenship ${ }^{3}$.

\footnotetext{
${ }^{2}$ Spouses of Icelandic citizens are exempted from this rule.

3 Iceland abolished the prohibition of double citizenship only in the 21st century, Amendment 9/2003 to the 1952 Act (Jóhannesson et al. 2013:17).
} 
Organisation for Economic Co-operation and Development (OECD) data for 2015 show that the level of naturalization in EU and EEA countries among citizens born in Europe is lower than the corresponding figures for third-country nationals. The opening of borders and the extension of civil and social rights to all EEA countries made naturalization for internal migrants neither necessary nor attractive. The OECD reports that fewer than half of migrants who are EU and EEA citizens decide to naturalize in the host state. It is quite different in the case of Europeans who have migrated to the USA, Canada or Australia, in whose case the naturalization rate is over $80 \%$ (OECD/ EU 2015). This pattern is confirmed by immigrants in Iceland. A much higher percentage of third-country nationals apply for Icelandic citizenship than Poles. In 2016, only 13\% of Poles living in Iceland had Icelandic citizenship, with the corresponding figure for Filipinos standing at $70 \%$ (Statistics Iceland 2016).

Reasons for applying for the status of a citizen - proximate mechanisms

In 2014, many Polish immigrants residing in Iceland were already eligible to apply for naturalization, having lived there for at least 7 years. As described previously, the privileged position of Polish immigrants in relation to immigrants from third countries means that applying for naturalization is not a necessity but rather a free choice. Thereby, there is a variety of motives accompanying the decision to apply for Icelandic citizenship. The absence of the need to apply for citizenship results in different attitudes of Polish migrants towards citizenship as such. Generally, two types of attitudes can be discerned: acceptanceand rejection, which take place on two dimensions: rational and symbolic. These attitudes are manifested both toward the Polish and Icelandic citizenship. Poles in Iceland are definitely guided by rationality in justifying their (possible) application for Icelandic citizenship. 
The rational dimension refers to the immigrant's weighing the arguments for and against drawn from various areas of life: immigrants estimate the benefits they can gain from Icelandic citizenship. The decision in favor of naturalization is not an act of accession to the political community, but a rational calculation of profits and costs. From the point of view of Polish immigrants, applying for naturalization is ambiguous in the perspective of benefits and losses. What is more, benefits and losses resulting from taking or not this decision have also material and non-material dimensions.

The analysis made it possible to distinguish the following narratives the naturalization in Iceland: citizenship as a pass, citizenship as a factor equalizing opportunities, citizenship as a political empowerment, and citizenship as an insurance policy.

\section{Citizenship as a pass - consumer integration}

The first reason for obtaining Icelandic citizenship is travelling with an Icelandic passport and the benefits that come with it. Icelandic citizens do not have to apply for visas to many countries around the world, including the United States of America, which was a very frequent argument for naturalization given by the respondents. Notably, it was often the only one that convinced Polish immigrants: "There will be more opportunities, because you can enter 153 countries on the Icelandic passport, you also do not need a visa to America, Canada or these countries. So, it's great" $(22)^{4}$.

The perception of the Icelandic passport as much better than the Polish one is somewhat exaggerated. First of all, Polish citizens can enter Canada without visas. Secondly, the ranking of passports conducted in 2016 by Henley \& Partners shows that the Icelandic passport is not as advantageous as the respondents believe and is only slightly better

${ }_{4}^{4}$ After each interview citation there is an interview index number given. 
than the Polish passport. The Icelandic passport was classified in the 10th place together with the Hungarian and Czech passports giving visa-free access to 167 countries. The Polish passport was placed in the 15th place allowing for visa-free entry to 161 countries. The ranking includes 104 positions. The attractiveness of the Icelandic passport seems to be symbolic: it allows visa-free entry into the United States of America, which since the nineteenth century has been the traditional destination of Polish emigration: until 2004 the USA had been the second Polish emigre country bettered only by the Federal Republic of Germany (Henley \& Partners 2016).

The narrative of the respondents revealed the citizen-consumer, for whom citizenship is a good-pass to satisfy their desire to cross the border of a mythical country, which for many still means the United States. The possibility of visa-free travel is also associated with higher position stratification in the post-modern world (Bauman 1998).

Obtaining a passport that gives a person more freedom to move between countries is a post-modern class promotion to the first world. This is a world of tourists for whom borders are of no consequence be cause, having a "good passport" to show, they can easily cross them (and be welcome in the destination country). They live only in the temporal dimension, space ceasing to be a limitation. The alter ego of such a tourist is a vagabond who, unlike a tourist for whom the good passport opens up borders, is forced to plod through subsequent migration checks, as his inferior passport makes them a person unwanted in many places.

This type of motivation can also be interpreted using the one of Max Weber categories (2013). The respondents' motivation to acquire an Icelandic passport has its source in the still strong affection that Poles feel for the United States. A distant America, whose reality an average Pole knows little of, remains a stable element of Polish national mythology (see Napiórkowski 2018). For this reason, applying for Icelandic 
citizenship can be treated as an affective act, one that would give access to the imagined Promised Land.

Citizenship is often referred to as a "passport" and it is the dominant way of talking about this legal status. Perceiving Icelandic citizenship as a "passport" separates citizenship from national identity (I am applying for an Icelandic passport, but not for Icelandic identity; I am still a Pole) and, in some way, it also separates citizenship from the state. Getting a passport might have been seen not as a long-lasting commitment and one did not have to approach the naturalization process in a principled manner. Naturalization might have a provisional character, until the next time the migrant applies for another naturalization after moving to another country. Among the surveyed Poles in Iceland, this is definitely the dominant way of perceiving citizenship and the main type of integration.

Citizenship as an insurance policy - integration through cautiousness

The second motive that guided the respondents towards naturalization was need of security and a kind of cautiousness. One of the interlocutors did not feel the need to have Icelandic citizenship (and also did not meet the formal conditions of applying for citizenship), but she kept in mind the future possibility of naturalization, treating it at the same time as something that "cannot do any harm" and may be useful one day. In the case described, citizenship was somewhat treated as a free collateral: "Well, it does not hurt. It is not that I want to become Icelandic, as I am Polish and I will always be Polish, but if I have already made my decision to move here... I think it will not do any harm me" (15).

This approach to citizenship shows that the respondent thought about it only in the category of rights and safeguards, disregarding the responsibilities that stem from it. The treatment of Icelandic citizenship as an insurance policy is in line with what Ulrich Beck describes as 
standing on a barricade against risk (1992). The respondent does not articulate fears about a possible anti-immigration sentiment in Iceland or Poland's exit from the European Union, but wants to have some extra protection against possible, still unnamed risks, which she estimates not on the basis of her own experience but some rather general knowledge. The risk against which she safeguards herself has its source in the supra-unit conditions related to macro and mega structures of the receiving and sending societies and the European Union (distal mechanisms).

Citizenship as equal opportunities - rational integration

The third of the arguments invoked by the respondents was related to the leveling of chances between Icelanders and immigrants. Those who have used this argument were convinced that the Icelandic state favours its citizens against those who do not have Icelandic citizenship. Inequities mentioned by the respondents concerned various areas of life.

One of the issues raised was the possibility of acquiring land, to which only Icelandic citizens have the right: “[...] because if I don't have an Icelandic passport, if I'm not fully Icelandic... Well, foreigners can't buy land. [...] I want to buy it because it's a good business" (31). In the case cited, the ineligibility to buy land collided with business plans of the respondent - he wanted to start another business, in his opinion profitable, but the lack of citizenship prevented him from it. Therefore, the decision to apply for Icelandic citizenship was marked by rationality.

Another case connected to equal opportunities related to the possibility of obtaining benefits from the Icelandic state: the respondent wanted to get a student loan to study abroad "I would definitely need Icelandic citizenship to get such a big loan for studying abroad" (25).

Motives of both interlocutors were investment-related: they were linked to improving the respondents' economic situation, by setting 
up a new business in the first case or investing in education in the other. Another respondent referred to equal opportunities in general - citizenship equates the chances of immigrants and Icelanders because it gives the opportunity to vote in elections: "Paying taxes in this country, I want to be treated equally, be acknowledged that I am here, I live here, I have a voice" (17). Those immigrants believed that investment in Icelandic citizenship would bring a high return (high EU weight).

In the narratives presented, citizenship is an instrument that equalizes chances as well as gives and protects the rights of the individual. Thus, citizenship is close to the concept of "thin citizenship", which amounts to a legal status: "Citizenship ties the individual [immigrant MN] to the state rather than to the political community" (Baubock 1999, pp. 6-7). Civil rights were perceived through the prism of negative freedom, leaving decisions about the community and involvement in its life and matters beyond the interests of the prospective citizen.

Citizenship as political empowerment - integration through commitment

Another motivation toward taking steps to acquire citizenship was the opportunity it would give one to decide on the socio-political situation in Iceland: "[...] the thing that interests me in citizenship is to take part in parliamentary elections [...], and besides that? I don't need to [apply for citizenship - M.N]" (21). The quote given above shows that respondents can identify citizenship with political commitment and the possibility to decide the community in which they are currently residing, rather than only as an element facilitating life in Iceland (thick citizenship Baubock 1999). The need to have a voice on the socio-political situation may also be associated with having children in Iceland, especially in the case of immigrants whose child was born on the island: "I want to vote, for me it is very important that in this place, where I and [...] my child live, that I have the right to speak" (17). 
Another factor strengthening the willingness to co-decide about the community was the fact that some actions of Icelanders were perceived as lacking rationality, like the restoration of the Independence Party to power in the parliamentary elections in 2013, the same party that had led to the crisis in 2008: "[...] one feels so powerless that nothing can change anymore, the party wins, [...] but my vote wouldn't have weighed in much, but it seems to me that the idea is growing on me, for practical reasons, and maybe because I know now better what's going on here [...] that I can actually vote, but I took part in these local [elections - MN]" (5).

This statement, despite the expressed feeling of helplessness and lack of faith in the unitary driving force, was still optimistic, as it considered voting as a conscious act, requiring some knowledge, especially at the level of national elections during which decisions about the whole society were made. It is significant (and quite unusual) that the respondents referred to rational arguments: to be able to improve their situation in the host country, they should have an impact on the political decisions made there regarding the structural conditions within which they operate.

In addition to the cautious calculations whether to become an Icelandic citizen, there was also a motivation related to non-rational categories. One of the respondents admitted that she wants to have Icelandic citizenship because she lives in Iceland and there is her home: "Because I'm not planning to return to Poland at all. Well, I don't know what tomorrow will bring, what will happen next year, but as of today I'm not planning on returning there. Here is my home, I want to stay here and that's why I want to get this citizenship, because I decided to live here" (3). While, on the one hand, the respondent stresses her plans for the future and the fact that Iceland is her home, which is unusual not only for Poles in Iceland but for post-accession liquid migrants on the whole, on the other hand she allows the possibility that the situation will 
change and she might have to leave island, which is a typical strategy characterizing liquid migration.

\section{Summary}

Citizenship of the European Union and the rights resulting from it, including the right to free movement of individuals and employees, has made migration an open project, and migration paths are now built according to socio-economic-political factors and individual needs of migrants. Citizenship as an inclusion/ exclusion tool and a mechanism granting rights has lost much of its importance. For this reason, very few Polish immigrants in Iceland decide to take steps to acquire the citizenship of the host country.

As a result of the analysis, four main motivations for adopting Icelandic citizenship were distinguished:

1) the possibility of visa-free travel to the USA - citizenship as a pass (consumer integration);

2) applying for citizenship "just in case" - citizenship as an insurance policy (integration through cautiousness);

3) obtaining rights that only indigenous people have - citizenship as a safeguard of equal opportunities (rational integration); and

4) the ability to decide about the community in which they live citizenship as a political empowerment (integration through commitment).

However, the main type of citizenship narrative was to treat it as a pass (consumer integration) - the other types of narratives were in the substantial minority. 
References

Ager A., Strang A. (2004), Indicators of Integration. Final Report, Home Office, London

Alba R., Nee V. (2003), Remaking the American Mainstream. Assimilation and Contemporary Immigration, Harvard University Press, CambridgeLondon

Baubock R. (1999), National Community, Citizenship and Cultural Diversity, Institute for Advanced Studies, Vienna

Bauman Z. (1998), Globalization: The Human Consequences, Columbia University Press, New York

Beck U. (1992), Risk Society: Towards a New Modernity, Sage Publications, London

Berry J.W. (1997), Immigration, Acculturation and Adaptation, "Applied Psychology: An International Review”Vol. 46, No. 1

Blomeraad I., Korteweg A., Yurdakul G. (2008), Citizenship and Immigration: Multiculturalism, Assmililation, and Challenges to the Nation-State, "Annual Review of Sociology" Vol. 34

Bukowska X., Wnuk-Lipiński E. (2009), Obywatelskość a la polonaise - czyli jakimi obywatelami sq Polacy [Citizenship a la Polonaise - What Citizens Poles Are?], „Nauka” No. 1

Castles S., Davidson A. (2000), Citizenship and Migration. Globalization and politics of belonging, Routledge, New York

Castles S., Korac M., Vasta E., Vertovec S. (2002), Integration: mapping the field, Report of a Project carried out by the University of Oxford Centre for Migration and policy Research and Refugee Studies Centre contracted by the Home Office Immigration Research and Statistics Service, Oxford

Esser H. (2010), Assimilation, Ethnic Stratification, or Selective Acculturation? Recent Theories of the Integration of Immigrants and the Model of Intergenerational Integration, „Sociologica”, Fascicolo 1, DOI: 10.2383/32055 
Glazer N. (1993), Is assimilation dead?, "The Annals of the American Academy of Political and Social Science" Vol. 530

Gordon M. (1964), Assimilation in American Life, Oxford University Press, New York

Grzymała-Kazłowska A. (2008), Integracja - próba rekonstrukcji pojęcia [Integration - an attempt to reconstruct the concept], (in:) Problemy integracji imigrantów. Koncepcje, badania, polityki [Problems of immigrant integration. Concepts, research, policies], (Eds.) Grzymała-Kazłowska A., Łodziński S., Wydawnictwo Uniwersytetu Warszawskiego, Warszawa

Henley \& Partners (2016), Visa Restriction Index, https://www.henleyglobal.com/ files/download/HP/ hvri/ HP\%20Visa\%20Restrictions \%20Index\%20160223.pdf

Icelandic Nationality Act (1952), No. 100/ 1952 (23 December), https://www. legislationline.org/ documents/id/5320

Jóhannesson G.T., Petursson G.T., Bjornsson T. (2013), Country report: Iceland, EDUO Citizneship Observatory, Robert Schuman Centre for Advanced Studies, European University Institute, Florence, http:/ / eudo-citizenship.eu/admin/ ?p=file\&appl=countryPro-files\&f=Iceland.pdf

J oppke Ch. (2010), Citizenship and migration, Polity Press, Cambridge

Morawska E. (1994), In Defense of Assimilation Model, "J ournal of American Ethnic History" Vol. 13, No. 2

Murray D. (2017), The Strange Death of Europe: Immigration, Identity, Bloomsbury Continuum, London

Napiórkowski M. (2018), Stany Iluzji [The US of Illusion], „Tygodnik Powszechny” No. 16, https:// www.tygodnikpowszechny.pl/stany-iluzji-152628

OECD/ EU (2015), Civic engagement of immigrants, (in:) Indicators of Immigrant Integration 2015: Settling In, OECD Publishing, Paris, http:// dx.doi. org/ 10.1787/9789264234024-14-en

Okólski M. (2009), Polska jako aktor na europejskiej scenie migracyjnej [Poland as an actor on the European migration scene], (in:) Wspótczesne migracje: dylematy Europy i Polski [Contemporary migrations: dilemmas 
of Europe and Poland], (Eds.) Duszczyk M., Lesińska M., Ośrodek Badań nad Migracjami, Uniwersytet Warszawski, Warszawa

Portes A., Zhou M. (1993), The New Second Generation: Segmented Generation and Its Variants, "The Annals of the American Academy of Political and Social Science" Vol. 530

Preuß U.K. (1993), O teoretyczno-konstytucyjnym pojęciu obywatelstwa we wspótczesnym spoleczeństwie [On the theoretical and constitutional concept of citizenship in contemporary society], (in:) Obywatel: odrodzenie pojęcia [Citizen: the rebirth of the concept], (Ed.) Markiewicz B., IFiS PAN, Warszawa

Raciborski J. (2010), Wprowadzenie: oblicza obywatelstwa [Introduction: citizienship], (in:) Praktyki obywatelskie Polaków [Poles: Citizenship practices], (Ed.) Idem, IFiS PAN, Warszawa

Scheffer P. (2011), Immigrant Nation, Polity Press, Cambridge

Statistics Iceland (2016), Foreign citizens gaining Icelandic citizenship by country of birth, sex and age 1991-2016, http://px.hag-stofa.is/pxen/pxweb/ en/Ibuar/Ibuar_mannfjoldi__3_bakgrun-nur__Rikisfbr/MAN04120.p x/table/ ta-bleViewLayout1/ ?rxid=148f64bb-3774-46ed-a739-4edoc34b0b5a [09.05.2017]

Statistics Iceland (2017), Population by country of birth, sex and age 1 January 1998-2017, http:// px.hagstofa.is/ pxen/pxweb/ en/Ibuar / Ibuar__man nfjoldi_3_bakgrunnur__Faedingarland/MAN12103.px/table/tableView Layout1/ ?rxid=148f64bb-3774-46ed-a739-4edc c34b0b5a [09.05.2017]

Trevena P. (2008), Teorie i doktryny dotyczqce integracji imigrantów. Doświadczenia tradycyjnych i nowych kręgów kulturowych [Theories and doctrines regarding integration of immigrants. Experiences of traditional and new cultural circles], (in:) Problemy integracji imigrantów. Koncepcje, badania, polityki [Problems of immigrant integration. Concepts, research, policies], (Eds.) Grzymała-Kazłowska A., Łodziński S., Wydawnictwo Uniwersytetu Warszawskiego, Warszawa

Weber M. (2013), Economy and Society, University of California Press, Oakland 
Wu S., Schimmele Ch.M., Hou F. (2012), Self-perceived Integration of Immigrants and Their Children, "Canadian J ournal of Sociology" Vol. 37, No. 4 